\title{
Extrapolation of Carcinogenicity Data to Low Doses with a Dose-Response Study of the Binding of Benzo(a)pyrene to Rat Liver DNA
}

\author{
W.K. Lutz and Ch. Schlatter \\ Institut für Toxikologie, Eidgenössische Technische Hochschule und Universität Zürich, \\ $\mathrm{CH}-8603$ Schwerzenbach, Switzerland
}

\begin{abstract}
The binding of tritiated benzo(a)pyrene (BP) to liver DNA of 25 adult male rats (SIV 50) has been determined $50 \mathrm{~h}$ after a single intraperitoneal injection of doses between $40 \mathrm{ug} / \mathrm{kg}$ and $4 \mathrm{mg} / \mathrm{kg}$. The dose-response relationship is linear up to $1 \mathrm{mg} / \mathrm{kg}$, shows a sigmoid step towards $2 \mathrm{mg} / \mathrm{kg}$ and a shallow linear slope above that value. The observed binding ranges from 1.7 to 180 nmoles BP per mole DNA phosphate. The non-linearity between 1 and $2 \mathrm{mg} / \mathrm{kg}$ could be explained on the basis of an induction of metabolizing enzymes.

A purely mathematical extrapolation of the tumour incidence from a carcinogenic dose ( $1 \times 40 \mathrm{mg} / \mathrm{kg}$ for a $20 \%$ hepatoma incidence in newborn mice) to human exposure levels (about $0.1 \mathrm{ug} / \mathrm{kg}$ per day) would never have followed a step like the one found in our experiments. Our dose-effect study therefore shows how carcinogenicity data could be extrapolated in a biologically founded way to low doses.
\end{abstract}

\section{Introduction}

For the estimation of the human risk of a chemically induced cancer from long-term carcinogenicity studies an extrapolation to lower doses is often done by means of different statistical approximations (Mantel and Schneiderman, 1975), none of which could take into account the actual course of.events governing the interaction of the chemical with the intact animal.

It is now widely accepted that one possible mechanism leading to a chemically induced tumour involves binding of the chemical or one of its metabolites to DNA (Miller, 1970). With the use of radioactive compounds this interaction can be measured with doses much lower than the ones used in long-term studies and the time needed for an evaluation of a compound can be reduced to a few days.

We report the results of a study of the binding of $40 \mu \mathrm{g} / \mathrm{kg}$ to $4 \mathrm{mg} / \mathrm{kg}$ tritiated benzo(a)pyrene (BP) to liver DNA of adult male rats so extending a similar study by Prodi et al. (1970) who used $1.2 \mathrm{mg} / \mathrm{kg}$ only. Our data illustrate the complexity of a low dose-response curve and its usefulness for reducing the uncertainties of an extrapolation from high-dose data. 


\section{Materials and Methods}

General Procedure. Generally tritiated BP was obtained from the Radiochemical Centre, Amersham. Adult male rats (SIV 50, Sprague Dawley derived, 260-340 g) were given a single i.p. injection of 1.5 to $3 \mathrm{mCi} / \mathrm{kg}$, diluted with inactive $\mathrm{BP}$ to the dose desired, in $0.5 \mathrm{ml}$ sunflower oil. After $50 \mathrm{~h}$, the liver was excised under ether anaesthesia, frozen over liquid nitrogen and stored at $-20^{\circ}$ until further use. The big liver lobe was treated according to Markov and Ivanov (1974) by a method yielding a DNA with maximal contaminations of $1 \%$ RNA and $0.1 \%$ protein. $1-2 \mathrm{mg}$ dried DNA were redissolved in $0.014 \mathrm{M}$ sodium phosphate buffer, $\mathrm{pH} 6.8$, and counted in $10 \mathrm{ml}$ Insta-Gel (Packard). The net counts ranged from 15 to $250 \mathrm{cpm}$. Treatment of this DNA with RNAse and Trypsin did not reduce the specific activity, nor did repeated washing with ethanol/ether $2: 1$.

Removing of Intercalated BP from DNA (Control Experiment). $0.1 \mathrm{mCi}$ tritiated BP were incubated for two hours with $25 \mathrm{ml}$ homogenate of $4 \mathrm{~g}$ liver in $8 \mathrm{M}$ urea and $0.24 \mathrm{M}$ sodium phosphate, $\mathrm{pH} 6.8$, containing $1 \%$ sodium dodecyl sulfate. The specific activity of the DNA isolated from that homogenate was around $2 \mathrm{cpm} / \mathrm{mg}$ DNA.

\section{Results}

The binding of BP to liver DNA as a function of the dose administered is depicted in Figure 1. It shows a linear rise up to approximately $1 \mathrm{mg} / \mathrm{kg}$, a sigmoid deflection towards $2 \mathrm{mg} / \mathrm{kg}$ and a shallow slope above that value. The points were divided into groups of 14 and 11 values below and above the presumed step. The linear regressions calculated from the two groups show clearly that the step is statistically significant.

It is well known that BP requires metabolic activation (Sims, 1976) before it can undergo its covalent interaction with other molecules. The enzyme system responsible for this activation, the aryl hydrocarbon hydroxylase (AHH, E.C. 1.14.14.2.) is inducible by many chemicals, including BP. A single dose of $2 \mathrm{mg} \mathrm{BP} / \mathrm{kg}$ can cause a 2 -fold increase in activity by three hours and a 5 -fold increase by $12 \mathrm{~h}$. The non-linearity in Figure 1 lies in the same dose range and is therefore most probably due to an induction of this activating enzyme system.

The higher variability of the binding values with higher doses as opposed to the lower ones may reflect individual differences in the enzyme inducing capabilities of the animals.

The control experiment described in the previous section showed that the radioactivity measured on the DNA is covalently bound. The incorporation of tritium lost from $\mathrm{BP}$ into DNA can also be neglected since it has been shown that tritium is almost quantitatively retained during the oxidation of $\mathrm{BP}$ in the organism and that only little tritiated water is incorporated into DNA within 50 hours. The radioactivity measured on the DNA therefore reflects a true binding of a BP metabolite. 


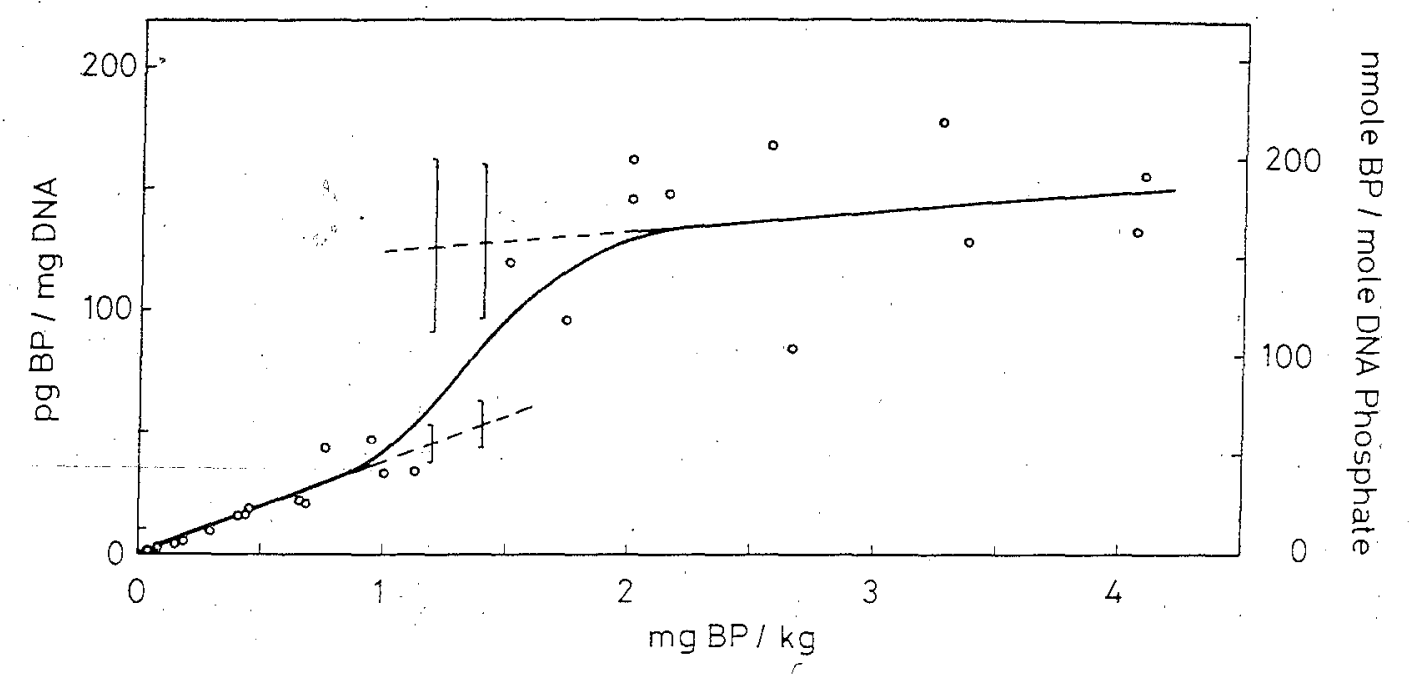

Fig. 1. Binding of tritiated benzo (a) pyrene to rat liver DNA $50 \mathrm{~h}$ after single i.p. injection, as a function of the dose administered. Each circle represents 1 animal. The vertical bars at 1.2 and $1.4 \mathrm{mg} / \mathrm{kg}$ cover \pm 2 standard deviations calculated from the two regressions with the values below and above the non-linearity

\section{Discussion}

The intake of $\mathrm{BP}$ by humans is strongly dependent upon. the living conditions and ranges in the order of $0.1 \mu \mathrm{g} / \mathrm{kg}$ per day. A purely mathematical extrapolation of the tumour incidence from a dose carcinogenic in new-born mice (20\% hepatoma incidence after a single injection of $4.0 \mathrm{mg} / \mathrm{kg}$ ) to these human exposure levels would never have followed a step like the one found in our experiments. Our dose-effect study therefore helps to improve the extrapolation of carcinogenicity data to low doses in a biologically founded way.

With the data presented we can still not attempt to calculate any figure for a human tumour incidence since our limit of detection is not low enough and since a single dose cannot represent a continued environmental exposure. Furthermore, our measured damage to the DNA does not necessarily lead to a transformation of a cell or to the growth of a tumour. Nevertheless, we believe that this type of in vivo approach will ultimately be needed for a toxicological evaluation of chemical carcinogens.

\section{References}

Mantel, N., Schneiderman, M.A.: Cancer Research 35, 1379 (1975)

Markov, G.G., Ivanov, I.G.: Analytical Biochemistry 59, 555 (1974)

Miller, J.A.: Cancer Research 30,559 (1970)

Prodi, G., Rocchi, P., Grilli, S.: Cancer Research 30, 1020 (1970)

Sims, P.: In: Screening Tests in Cbemical Carcinogenesis, Vol. 12, p. 211. (R.

Montesano, H. Bartsch and L. Tomatis, eds.), International Agency for Research on Cancer, Lyon, France, 1976 